Artikel Penelitian

\title{
Gambaran Jumlah Trombosit Berdasarkan Berat Ringannya Penyakit pada Pasien Sirosis Hati dengan Perdarahan di RSUP Dr. M. Djamil Padang
}

\author{
Fadhilah Al Hijjah¹, Rismawati Yaswir², Nur Afrainin Syah ${ }^{3}$
}

\begin{abstract}
Abstrak
Komplikasi yang sering terjadi pada pasien sirosis hati adalah perdarahan yang dapat disebabkan oleh penghancuran sel-sel darah berlebihan sehingga berakibat terhadap penurunan jumlah sel-sel darah termasuk trombosit. Tujuan penelitian ini adalah untuk mengetahui gambaran jumlah trombosit berdasarkan berat ringannya penyakit pada pasien sirosis hati dengan perdarahan di RSUP Dr. M. Djamil Padang. Penelitian ini merupakan studi deskriptif retrospektif. Sampel penelitian berjumlah 78 orang yang merupakan pasien sirosis hati dengan perdarahan yang memenuhi kriteria inklusi dan ekslusi. Nilai trombosit yang digunakan adalah nilai trombosit yang diukur menggunakan alat hematology analyzer. Data kemudian dianalisis secara deskriptif dan disajikan dalam bentuk tabel. Hasil penelitian menunjukkan penderita terbanyak sirosis hati dengan perdarahan pada kelompok umur 58 - 63 tahun dan penderita terbanyak adalah laki-laki, yaitu sebanyak $56(71,8 \%)$ orang. Sebanyak $52(66,7 \%)$ penderita sirosis hati dengan perdarahan memiliki jumlah trombosit yang rendah. Klasifikasi penyakit sirosis hati perdarahan Child $A$ sebanyak $11(14,1 \%)$ orang dengan rerata jumlah trombosit $192.181 / \mathrm{mm}^{3}$, Child B sebanyak $32(41 \%)$ orang dengan rerata jumlah trombosit $155.687 / \mathrm{mm}^{3}$, dan Child C sebanyak $35(44,9 \%)$ orang dengan rerata jumlah trombosit $96.485 / \mathrm{mm}^{3}$. Simpulan hasil penelitian ini adalah jumlah trombosit pasien sirosis hati dengan perdarahan semakin menurun sesuai dengan derajat berat ringannya penyakit sirosis hati.
\end{abstract}

Kata kunci: trombosit, sirosis hati, perdarahan

\section{Abstract}

The most common complication in patients with liver cirrhosis was bleeding that can be caused by excessive destruction of blood cells, resulting to reduce the number of blood cells, including thrombocyte. The objective of this study was to describe the thrombocyte number based on the severity of disease in patients with bleeding liver cirrhosis in RSUP Dr. M. Djamil Padang. This study is a retrospective descriptive study. These samples included 78 people who are bleeding liver cirrhosis patients that included the inclusion and exclusion criteria. Thrombocyte number used was measured using a hematology analyzer tool. Data were analyzed descriptively and presented in tabular form. The results showed most patients with bleeding liver cirrhosis in the age group 58-63 years and most patients were male, as many as 56 (71.8\%) people. A total of 52 (66.7\%) patients with bleeding liver cirrhosis have a low thrombocyte count. Classification of bleeding liver cirrhosis Child $A$ total 11 (14.1\%) people with a mean thrombocyte number $192.181 / \mathrm{mm}^{3}$, Child B 32 (41\%) people with a mean thrombocyte number $155.687 / \mathrm{mm}^{3}$, and Child C a total of 35 (44, 9\%) people with a mean thrombocyte number $96.485 / \mathrm{mm}^{3}$. The conclusion of this study is the thrombocyte number in bleeding liver cirrhosis patients decreased in accordance with the degree of severity of liver cirrhosis.

Keywords: thrombocyte, liver cirrhosis, bleeding

Affiliasi penulis: 1. Prodi Profesi Dokter FK Unand (Fakultas Kedokteran Universitas Andalas), 2. Bagian Patologi Klinik FK Unand/ RSUP Dr. M. Djamil Padang, 3. Bagian Anatomi FK Unand
Korespondensi: Fadhilah Al Hijjah, Email: alhijjah10@gmail.com Telp: 082388541119 / 081906235155 


\section{PENDAHULUAN}

Sirosis hati dapat didefinisikan sebagai suatu keadaan patologis yang menggambarkan stadium akhir dari proses fibrosis hati difus yang berlangsung progresif yang ditandai dengan distorsi arsitektur hati dan pembentukan nodul degeneratif. ${ }^{1}$

Penyakit ini termasuk dalam 20 penyebab kematian terbanyak di dunia dan masuk ke dalam 5 besar penyebab kematian di Indonesia. ${ }^{2}$ Kematian yang disebabkan oleh sirosis hati pada tahun 2004 di South East Asia Region B (Indonesia, Sri Lanka, Thailand) adalah sejumlah 38.382 kasus dengan 25.326 kasus pada pria dan 13.056 kasus pada wanita. ${ }^{3}$ Pada tahun 2008 , kematian akibat sirosis hati di South East Asia Region B tersebut meningkat menjadi 51.715 kasus dengan 38.187 kasus pada pria dan 13.528 kasus pada wanita. ${ }^{4}$

Data resmi prevalensi sirosis hati di Indonesia belum ada, hanya berupa laporan dari beberapa pusat pendidikan saja. $^{5}$

Perjalanan penyakit sirosis hati lambat, asimtomatis dan seringkali tidak dicurigai sampai munculnya komplikasi penyakit hati yang lain. Manifestasi klinis dari penyakit sirosis hati terjadi akibat dua tipe gangguan fisiologis, yaitu gagal sel hati dan hipertensi portal. Manifestasi gagal sel hati mencakup ikterus, gangguan endokrin, gangguan hematologik, edema perifer, fetor hepatikum, dan ensefalopati hepatik, sedangkan manifestasi yang berkaitan dengan hipertensi portal yaitu splenomegali, varises esofagus dan lambung, serta manifestasi sirkulasi kolateral lain. ${ }^{6}$

Gangguan hematologik yang sering terjadi pada sirosis hati adalah kecenderungan perdarahan, anemia, leukopenia, dan trombositopenia. ${ }^{6}$ Perdarahan yang terjadi pada sirosis hati dapat bervariasi dari yang paling ringan seperti ekimosis sampai yang paling berat dan mengancam nyawa seperti perdarahan saluran cerna bagian atas. ${ }^{7}$
Komplikasi yang sering terjadi pada pasien sirosis hati adalah perdarahan yang bahkan dapat menyebabkan kematian pada pasien tersebut. Faktor utama penyebab komplikasi perdarahan yang terjadi yaitu berkurangnya faktor pembekuan akibat kerusakan dari sel-sel hati dan penghancuran sel-sel darah berlebihan yang berakibat terjadinya penurunan jumlah sel-sel darah termasuk trombosit. ${ }^{8}$ Trombosit yang fungsi utamanya sebagai pembentuk sumbat mekanis sebagai respon hemostasis normal akan terganggu fungsinya apabila jumlahnya menurun. ${ }^{9}$

Jumlah trombosit dan faktor pembekuan dapat rendah pada pasien sirosis hati dengan komplikasi perdarahan, namun kejadiannya berbeda pada setiap pasien. Pemeriksaan laboratorium yang dilakukan terhadap pasien dapat lebih memantau jumlah trombosit pasien dibandingkan dengan kadar faktor pembekuan karena tidak pada semua pasien dilakukan pemeriksaan terhadap kadar faktor pembekuannya. Atas dasar tersebut penulis tertarik untuk meneliti serta mengetahui gambaran jumlah trombosit berdasarkan berat ringannya penyakit pada pasien sirosis hati dengan perdarahan di RSUP Dr. M. Djamil Padang

\section{METODE}

Penelitian ini merupakan studi deskriptif retrospekstif. Populasinya yaitu penderita sirosis hati dari September 2014 sampai dengan Juni 2015 yang dirawat di Bagian Penyakit Dalam RSUP Dr. M. Djamil Padang. Sampel diambil dari populasi yang memenuhi kriteria inklusi dan ekslusi. Pengolahan data dilakukan secara manual serta dianalisa secara deskriptif untuk melihat karakteristik pasien sirosis hati dengan perdarahan dan dilakukan analisa statistik dengan uji statistik Anova untuk melihat perbedaan rerata jumlah trombosit pasien sirosis hati dengan perdarahan berdasarkan berat ringannya penyakit sirosis hati. 
HASIL

Tabel 1. Karakteristik sampel sirosis hati dengan perdarahan

\begin{tabular}{|c|c|c|}
\hline Variabel & $\begin{array}{c}\text { Jumlah Penderita } \\
\text { Sirosis Hati dengan } \\
\text { Perdarahan }\end{array}$ & $\%$ \\
\hline \multicolumn{3}{|l|}{ Umur } \\
\hline $34-39$ & 8 & 10,3 \\
\hline $40-45$ & 8 & 10,3 \\
\hline $46-51$ & 17 & 21,8 \\
\hline $52-57$ & 16 & 20,5 \\
\hline $58-63$ & 18 & 23,1 \\
\hline $64-69$ & 4 & 5,1 \\
\hline $70-75$ & 7 & 8,9 \\
\hline \multicolumn{3}{|c|}{ Jenis Kelamin } \\
\hline Laki-laki & 56 & 71,8 \\
\hline Wanita & 22 & 28,2 \\
\hline \multicolumn{3}{|c|}{ Klasifikasi CTP } \\
\hline Child A & 11 & 14,1 \\
\hline Child B & 32 & 41,0 \\
\hline Child C & 35 & 44,9 \\
\hline \multicolumn{3}{|l|}{ Jumlah } \\
\hline Trombosit & 26 & 33,3 \\
\hline Normal & 52 & 66,7 \\
\hline Rendah & & \\
\hline
\end{tabular}

Pada Tabel 1 didapatkan bahwa penderita sirosis hati dengan perdarahan terbanyak pada kelompok umur 58-63 yaitu sebanyak 18 orang $(23,1 \%)$. Rata-rata umur penderita adalah 53,7 tahun. Bila ditinjau dari jenis kelamin, penderita sirosis hati dengan perdarahan yang berjenis kelamin laki-laki lebih banyak ditemukan dibandingkan dengan wanita, yaitu 56 orang $(71,8 \%)$ pada laki-laki dan 22 orang $(28,2 \%)$ pada wanita.

Klasifikasi terbanyak penderita sirosis hati dengan perdarahan adalah Child $\mathrm{C}$ yaitu sebanyak 35 orang $(44,9 \%)$. Sementara penderita yang masuk dalam Child B sebanyak 32 orang (41\%) dan Child A sebanyak 11 orang $(14,1 \%)$. Jumlah trombosit yang normal pada penderita sirosis hati dengan perdarahan yang dirawat ditemukan sebanyak 26 orang $(33,3 \%)$ sedangkan yang mengalami penurunan jumlah trombosit sebanyak 52 orang $(66,7 \%)$.

Tabel 2. Gambaran rerata jumlah trombosit pasien sirosis hati dengan perdarahan berdasarkan berat ringan sirosis hati

\begin{tabular}{lccccc}
\hline Klasifikasi & $\mathbf{n}$ & \multicolumn{3}{c}{ Jumlah Trombosit $\left(\mathrm{mm}^{3}\right)$} & \\
\cline { 3 - 5 } Child & & Rerata \pm & Min & Max & $\mathbf{p}$ \\
& & SD & & & \\
\hline Child A & 11 & $192.181 \pm$ & 69.0 & 323.000 & \\
& & 78.378 & 00 & & \\
Child B & 32 & $155.687 \pm$ & 62.0 & 458.000 & 0,0001 \\
& & 80.842 & 00 & & \\
Child C & 35 & $96.485 \pm$ & 20.0 & 298.000 & \\
& & 57.871 & 00 & & \\
\hline Total & 78 & & & \\
\hline
\end{tabular}

Tabel 2 diatas menunjukkan nilai rerata jumlah trombosit pasien sirosis hati dengan perdarahan dengan klasifikasi penyakit sirosis hati Child $A$ adalah 192.181/mm $\mathrm{mm}^{3}$ (SD=78.378), pada Child B adalah $155.687 / \mathrm{mm}^{3}$ (SD=80.842), dan pada Child $C$ adalah $96.485 / \mathrm{mm}^{3} \quad(\mathrm{SD}=57.871)$. Terlihat bahwa terdapat perbedaan rerata jumlah trombosit pada ketiga klasifikasi tersebut. Perbedaan tersebut kemudian secara statistik dinilai bermakna dengan $p$ value $0,0001(p<0,05)$. Hasil statistik ini memperlihatkan terdapat perbedaan rerata jumlah trombosit pada pasien sirosis hati dengan perdarahan berdasarkan klasifikasi berat ringannya penyakit sirosis hati.

Penderita sirosis hati dengan perdarahan yang termasuk klasifikasi Child C cenderung mengalami trombositopenia. Hasil uji perbandingan ganda pada ketiga klasifikasi penyakit sirosis hati tersebut, didapatkan perbedaan hasil yang signifikan dari rerata Child A terhadap Child $C$ dengan $p=0,001(p<0,05)$, dan $p$ rerata Child $B$ terhadap Child $C 0,003(p<0,05)$. Hal ini menunjukkan terdapat perbedaan rerata jumlah trombosit yang bermakna antara Child $\mathrm{A}$ dengan Child $C$ dan antara Child B dengan Child $C$. Namun, $p$ value dari rerata Child A dengan Child B 0,436 ( $p>0,05)$ yang artinya tidak terdapat perbedaan rerata yang bermakna antara Child A terhadap Child B secara statistik, walaupun terdapat penurunan rerata jumlah trombosit pada Child B dibandingkan Child A. 


\section{PEMBAHASAN}

Berdasarkan hasil penelitian, penderita sirosis hati dengan perdarahan rata-rata berumur 53,7 tahun. Hasil ini tidak jauh berbeda dengan penelitian Regina (2011) di RSUP Dr. M Djamil yang menemukan penderita sirosis hati rata-rata berumur 50,26 tahun. Penelitian Simamora (2013) di Pontianak mendapatkan rerata umur 55,66 tahun pada penderita sirosis hati yang masih hidup dan 51,93 tahun pada penderita yang telah meninggal. ${ }^{10,11}$

Berdasarkan jenis kelamin, sirosis hati dengan perdarahan lebih banyak dialami laki-laki dibandingkan dengan wanita dengan perbandingan 2,5:1. Hasil ini tidak jauh berbeda dengan hasil penelitian yang didapatkan oleh Elfatma (2014) di RSUP Dr. M Djamil yang mendapatkan perbandingan laki-laki dan wanita 3:1. Penelitian Karina (2007) di RSUP Dr. Kariadi Semarang mendapatkan perbandingan penderita lakilaki dan wanita sebanyak $2: 1 .{ }^{12,13}$

Berdasarkan berat ringannya penyakit sirosis hati pada pasien sirosis hati dengan perdarahan yang dinilai dengan kriteria CTP, didapatkan penderita dengan kriteria Child A 14,1\%, Child B 41\%, dan Child C yang merupakan kondisi terbanyak yaitu $44,9 \%$. Hasil penelitian ini sebanding dengan yang didapatkan oleh Elfatma (2014) di RSUP Dr. M Djamil dengan penderita sirosis hati dengan Child A 9,1\%, Child B 43,9\%, dan Child C 47\% ${ }^{12}$. Tambunan (2012) di Pontianak juga mendapatkan Child A 3,3\%, Child B $37,5 \%$, dan Child C 53,3\% ${ }^{14}$. Berbeda dengan hasil penelitian Regina (2011) yang mendapatkan penderita sirosis hati dengan Child $C$ yang lebih sedikit dibandingkan dengan Child $\mathrm{A}$ dan Child $\mathrm{B}$, yaitu Child A $15,38 \%$, Child B 50,77\%, dan Child C 33,85\%. Perbedaan ini dapat terjadi karena data yang tidak lengkap dalam penelitian Regina sehingga tidak semua penderita dapat digolongkan kedalam klasifikasi ini, dan juga kriteria inklusi yang dipakai berbeda sehingga memungkinkan adanya sampel yang berbeda dalam kedua penelitian ini. ${ }^{10}$

Jumlah trombosit yang didapatkan pada pasien sirosis hati dengan perdarahan dibagi dalam dua kategori yaitu normal ( $>150.000 / \mathrm{mm}^{3}$ ) dan rendah $\left(<150.000 / \mathrm{mm}^{3}\right)$. Hasil penelitian yang didapat, penderita sirosis hati dengan perdarahan dengan jumlah trombosit normal sebanyak 26 orang (33,33\%) dan dengan jumlah trombosit rendah sebanyak 52 orang $(66,67 \%)$. Dari hasil penelitian ini, didapatkan pada penderita sirosis hati dengan perdarahan masih ada penderita yang memiliki jumlah trombosit yang normal. Hal ini menunjukan adanya faktor lain yang berperan dalam terjadinya perdarahan pada penderita sirosis hati selain dari jumlah trombosit.

Pada penelitian ini, penderita sirosis hati dengan perdarahan yang memiliki trombosit normal kemungkinan dipengaruhi oleh faktor lain selain dari trombositnya seperti gangguan sintesis faktor pembekuan dan antikoagulan, defisiensi bersihan hati, pembentukan faktor pembekuan yang abnormal, serta gabungan dari kelainan-kelainan tersebut. ${ }^{7}$

Berdasarkan Tabel 2, nilai rerata jumlah trombosit pada pasien sirosis hati dengan perdarahan yang masuk dalam klasifikasi Child A adalah 192.181/mm ${ }^{3}$ (SD78.378), pada Child B adalah $155.687 / \mathrm{mm}^{3}$ (SD 80.842), dan pada Child C adalah $96.485 / \mathrm{mm}^{3}$ (SD 57.871). Dari hasil penelitian tersebut didapatkan bahwa pasien sirosis hati dengan perdarahan pada derajat penyakit Child A dan B masih memiliki rerata jumlah trombosit yang normal, namun rerata pada Child $B$ lebih rendah dibanding dengan Child $A$, sedangkan rerata pada Child $C$ menunjukkan keadaan penurunan jumlah normal dari trombosit atau trombositopenia. Hal ini menunjukkan bahwa dalam perjalanan penyakitnya, semakin berat derajat kerusakan hati penderita maka semakin berkemungkinan untuk mengalami trombositopenia. Hasil penelitian serupa dengan hasil yang diperoleh Adinolfi et al (2001) menunjukkan bahwa prevalensi trombositopenia lebih tinggi pada derajat fibrosis hati yang telah lanjut. Hasil penelitian Giannini et al (2003) juga menunjukkan bahwa trombositopenia terjadi pada $76 \%$ dari pasien sirosis hati yang diteliti tanpa melihat ada atau tidaknya kejadian perdarahan pada penderitanya. ${ }^{15,16}$

Hasil penelitian ini memperoleh nilai $p=0,0001$ $(p<0,005)$ setelah dilakukan uji statistik Anova. Hal ini menunjukkan adanya perbedaan jumlah rerata trombosit yang bermakna pada pasien sirosis hati dengan perdarahan berdasarkan derajat penyakit sirosis hati Child A, B, dan C dengan semakin berat 
derajat penyakit sirosis hati yang diderita oleh penderita maka semakin rendah rerata jumlah trombosit yang didapatkan.

Hasil yang didapatkan pada uji perbandingan ganda ketiga klasifikasi derajat sirosis hati, didapatkan hasil yang signifikan dari rerata Child $A$ terhadap Child $C$ dengan $p$ value $0,001(p<0,05)$, dan $p$ value rerata Child $B$ terhadap Child C 0,003 $(p<0,05)$ yang artinya terdapat perbedaan rerata jumlah trombosit yang bermakna antara Child $\mathrm{A}$ dengan Child $\mathrm{C}$ dan antara Child $B$ dengan Child $C$. Namun, $p$ value dari rerata Child $A$ terhadap Child $B$ 0,436 ( $p>0,05)$ yang artinya tidak terdapat perbedaan rerata yang bermakna antara Child A terhadap Child B secara, statistik walaupun terdapat penurunan rerata jumlah trombosit pada Child B dibanding Child A. Hal ini bisa disebabkan oleh derajat kerusakan hati yang terjadi pada Child $B$ dan Child A tidak begitu jauh berbeda atau berperannya faktor-faktor lain yang menyebabkan perdarahan selain jumlah trombosit yang rendah, selain itu juga dapat disebabkan oleh jumlah sampel yang sedikit pada penelitian ini sehingga data yang ada tidak cukup menambahkan siginifikansi yang didapat melalui penghitungan secara statistik.

\section{SIMPULAN}

Terdapat perbedaan rerata jumlah trombosit yang bermakna pada pasien sirosis hati dengan perdarahan berdasarkan berat ringannya klasifikasi sirosis hati.

\section{UCAPAN TERIMAKASIH}

Terima kasih kepada staff bagian Penyakit Dalam, dan staff bagian rekam medik RSUP Dr. M. Djamil Padang yang telah membantu penulis dalam melakukan penelitian ini.

\section{DAFTAR PUSTAKA}

1. Nurdjanah S. Sirosis hati. Dalam: Buku Ajar IImu Penyakit Dalam. Edisi ke-6, jilid 2. Jakarta: Internal publishing; 2014. HIm.1978-83.

2. World Health Organization (WHO). The Global Burden of Disease 2010 (diunduh 6 Maret 2015). Tersedia dari: URL: HYPERLINK www.who.int
3. World Health Organization (WHO). The Global burden of disease 2004 (diunduh 3 Februari 2015). Tersedia dari: URL: HYPERLINK www.who.int

4. World Health Organization (WHO). The Global Burden of Disease 2008 (diunduh 3 Februari 2015). Tersedia dari URL: www.who.int

5. Nurdjanah S. Sirosis hati. Dalam:Buku Ajar Ilmu Penyakit Dalam. Edisi ke-5. Jakarta: Internal Publishing; 2009. hlm.668-73.

6. Lindseth GN. Gangguan hati, kandung empedu, dan pankreas. Dalam: Patofisiologi konsep klinis proses-proses penyakit. Edisi ke-6; Vol.1. Jakarta: EGC; 2013.hlm.472-515.

7. Tambunan KL. Gangguan hemostasis pada sirosis hati. Dalam: Buku ajar ilmu penyakit dalam. Edisi ke-6; jilid 2. Jakarta: Internal Publishing; 2014. hlm. 2800-06.

8. Armitage JO. Approach to the patient with lymphadenopathy and splenomegaly. In:Goldman's Cecil Medicine 24th Edition. USA: Saunders Elsevier; 2012. hlm. 1107-11.

9. Hoffbrand AV, Moss PAH. Kapita Selekta hematologi. Edisi ke-6. Jakarta: EGC; 2011. hlm. 293-306.

10. Regina, $\mathrm{V}$. Hubungan kadar limfosit total dengan prognosis penyakit pada penderita sirosis hati di bagian penyakit dalam (skripsi). Padang: Fakultas Kedokteran Universitas Andalas; 2011.

11. Simamora, Cika TA. Hubungan komplikasi, skor Child-Turcotte, dan usia lanjut sebagai faktor resiko kematian pada pasien sirosis hati di RSUD DR. Soedarso Pontianak tahun 2008-2012 (naskah publikasi). Pontianak: Universitas Tanjungpura. 2013.

12. Elfatma Y. Gambaran derajat varises esofagus berdasarkan beratnya sirosis hepatis (skripsi). Padang: Fakultas Kedokteran Universitas Andalas; 2014.

13. Karina. Faktor resiko kematian penderita sirosis hati di RSUP Dr. Kariadi Semarang tahun 20022006 (skripsi). Semarang: Universitas Diponegoro; 2007.

14. Tambunan A. Karakteristik pasien sirosis hati di RSUD dr. Soedarso Pontianak periode Januari 2008-Desember 2010 (skripsi). Pontianak: Universitas Tanjungpura; 2012. 
15. Adinolfi EL, Giordano MG, Andreana A, Tripodi MF, Utili R, Cesaro G, et al. Hepatic fibrosis plays a central role in the pathogenesis of trombocytopenia in patient with chronic viral hepatitis. British Journal of Haematology. 2001; 113:590-5.
16. Giannini E, Botta F, Borro P, Risso D, Romagnoli $\mathrm{P}$, Fasoli $\mathrm{A}$, et al. Platelet count/spleen diameter ratio: proposal and validation of a non-invasive parameter to predict the presence of esophageal varises in patient with liver cirrhosis. Gut. 2003; 53: 1200-05. 